\title{
Natural Bio-Remediation of Arsenic Contamination: A Short Review
}

\author{
Anil K Dwivedi', Shikha Srivastava ${ }^{1}$, Shashi Dwivedi ${ }^{2}$ and Vira Tripathi ${ }^{2}$
}

${ }^{1}$ Pollution and Environmental Assay Research Laboratory (PEARL), Department of Botany, D.D.U. Gorakhpur University, Gorakhpur-273009, U.P, India

${ }^{2}$ Department of Chemistry, St. John's School, Mehrauli, Varanasi-221108, U.P, India

\begin{abstract}
The present short review is an attempt to explain the importance and uses of arsenic. It also explains different researches which have been conducted for treatment of arsenic contamination; particularly the botanical tools or the plants. The paper also deals with the future prospects of the topic, guiding the future aspects.
\end{abstract}

Keywords: Arsenic; Phytoremediation; Phytoextraction; Groundwater; Hyperaccumulator

\section{Introduction}

The problem of water pollution is now a problem of commons, round the globe [1], but the problem of arsenic contamination in the groundwater is not too old. Arsenic (As) is a metalloid and it belongs to Nitrogen Group [Va] of the periodic table. The atomic number of Arsenic is 33 and atomic mass is 74.922. Arsenic is found as one stable isotope, ${ }^{75} \mathrm{As}$ which is non-radioactive. Arsenic appears in three allotropic forms: yellow, grey and black. Grey arsenic is most common. It burns in air to make arsenic trioxide which is highly toxic. Arsenic is usually very toxic, especially in the cases of inorganic arsenic compounds such as arsenic trichloride and arsenous acid.

The name Arsenic had come from 'arsenikon', the Greek name for the yellow pigment orpiment. Arsenic compounds were mined by the early Chinese, Greek and Egyptian civilisations. They discovered its toxic properties. It is believed that Albertus Magnus discovered arsenic in $1250 \mathrm{~A}$. D. He obtained it by heating soap together with orpiment (arsenic trisulphide, $\mathrm{As}_{2} \mathrm{~S}_{3}$ ). A more dangerous form of arsenic, called white arsenic, has also been long known. This was the trioxide, $\mathrm{As}_{2} \mathrm{O}_{3}$, and was a by-product of copper refining. When this was mixed with olive oil and heated it yielded arsenic metal itself. The first authentic report of the free arsenic was proposed in 1649 by Johann Schroeder, a German pharmacist, who prepared arsenic by heating its oxide with charcoal. Later, Nicolas Lémery, a French physician and chemist, observed the formation of arsenic during heating a mixture of the oxide, soap, and potash. By the 18th century, arsenic was well known as a unique metalloid. It was also termed as 'Poison of Kings' as it was used to kill several kings in $17^{\text {th }}$ and $18^{\text {th }}$ century [2].

Arsenic is widely distributed and it forms about $1.5 \mathrm{ppm}$ (parts per million) of the Earth's crust. It is found in sedimentary, igneous and metamorphic rocks. Mostly it is found in more than 150 different minerals such as sulfides, arsenides, sulfoarsenides, and arsenites. Mispickel or arsenopyrite (FeAsS) is the most common of arsenicbearing minerals; others are realgar $\left(\mathrm{As}_{4} \mathrm{~S}_{4}\right)$, Orpiment $\left(\mathrm{As}_{2} \mathrm{~S}_{3}\right)$, loellingite $\left(\mathrm{FeAs}_{2}\right)$ and enargite $\left(\mathrm{Cu}_{3} \mathrm{AsS}_{4}\right)$. Arsenic oxide is also common. Most commercial arsenic is recovered as a by-product of the smelting of copper, lead, cobalt, and gold ores. Arsenic also occurs in organic form. Organic arsenic is also found in water, natural gas and shale oil. It is found in human body due to liver enzyme activity [3].

Some examples of organic arsenic are Monomethylarsonic acid, Dimethyl arsinic acid and Trimethyl arsine oxide.

- Arsenic finds a variety of uses in our daily life, for example [4]:
- Arsenic is used in metallurgical applications because of its metalloid properties.

- It is also used in bronzing and pyrotechnics.

- It is also used as a doping agent for semi- conductors. Ex- Gallium Arsenide (GaAs) is used in diodes, lasers and transistors.

- Arsenic compounds are used in making special type of glass and wood preservative.

- It is also used in alloy.

- Arsenic a result of its toxicity it is used as insecticides and pesticides.

- Arsenic compounds of particular importance in agriculture are arsenic acid $\left(\mathrm{H}_{3} \mathrm{AsO}_{4}\right)$ and such salts as lead arsenate $\left(\mathrm{PbHAsO}_{4}\right)$ and calcium arsenate $\left[\mathrm{Ca}_{3}\left(\mathrm{AsO}_{4}\right)_{2}\right]$, which are useful for sterilizing soils and controlling pests respectively.

- Several complex organic compounds of arsenic have been employed in the treatment of certain diseases, such as amoebic dysentery, caused by microorganisms.

- It was used in medicine in $17^{\text {th }}, 18^{\text {th }}$ and $19^{\text {th }}$ century. Arsenic trioxide was used to treat cancer.

- Despite of its toxicity, arsenic is also necessary to our physiology. A level of $0.00001 \%$ is needed for growth and for a healthy nervous system.

\section{Hazardous effects of arsenic}

Arsenic is listed as the most hazardous substance according to the US agency for toxic substance and disease registry [2]. Arsenic menace is a global concern as it is a potent environmental pollutant as well as it causes enduring health hazards. Arsenic is widely distributed

*Corresponding author: Anil K Dwivedi, Pollution and Environmental Assay Research Laboratory (PEARL), Department of Botany, D.D.U. Gorakhpur University, Gorakhpur-273009, U.P, India, E-mail: anil.k.dwiwedi@gmail.com

Received October 07, 2014; Accepted January 22, 2015; Published January 24 2015

Citation: Dwivedi AK, Srivastava S, Dwivedi S, Tripathi V (2015) Natural BioRemediation of Arsenic Contamination: A Short Review. Hydrol Current Res 6: 186. doi:10.4172/2157-7587.1000186

Copyright: (c) 2015 Dwivedi AK, et al. This is an open-access article distributed under the terms of the Creative Commons Attribution License, which permits unrestricted use, distribution, and reproduction in any medium, provided the original author and source are credited. 
in environment. It is highly mobilized element and mainly cycled by water in the environment. Due to human activities, mainly through mining and smelting, arsenic can now be found on many more places than where they never existed before. Inorganic arsenic is highly toxic and adversely affects human health. Humans may be exposed to arsenic through food, water and air. Exposure may also occur through skin contact with soil or water that contains arsenic. Around 10 million people in India are unknowingly consuming high level of arsenic in their water. The current recommended limit of arsenic in drinking-water is $10 \mu \mathrm{g} /$ litre. A recent survey showed that the ground water of several parts of eastern Uttar Pradesh and Bihar contain far higher levels of arsenic than is considered safe and permissible for human consumption [4]. People are exposure to inorganic arsenic through drinking contaminated water, using contaminated water in food preparation and irrigation of food crops, industrial processes and smoking tobacco. Long term exposure to arsenic rich water can lead to chronic arsenic poisoning which is termed as Arsenicosis. The routes of Arsenic exposure is inhalation, ingestion and through skin and eye contact.

\section{Chronic exposure effects}

Long term exposure to arsenic is observed on the skin. It includes pigmentation changes, skin lesions and hard patches on the palms and soles of the feet (hyperkeratosis). These occur after a minimum exposure of approximately five years and may be a precursor to skin cancer.

In addition to skin cancer, long-term exposure to arsenic may also cause cancer of the bladder and lungs. International Agency for Research on Cancer (IARC) has classified arsenic and arsenic compounds as carcinogenic to humans. IARC has stated that arsenic in drinking-water is carcinogenic to humans. Inorganic arsenic is classified as a Class A Carcinogen or Human Carcinogen by the U.S. Environmental Protection Agency when exposed in ingestion or inhalation [2]. Other health hazards include peripheral neuropathy, gastrointestinal symptoms, conjunctivitis, diabetes, renal system effects, enlarged liver, bone marrow depression, destruction of erythrocytes, high blood pressure and cardiovascular disease.

In China exposure to arsenic through drinking water has been shown to cause a severe disease of the blood vessels, which leads to gangrene, known as 'black foot disease'. This disease has not been observed in other parts of the world, and it is possible that malnutrition contributes to its development. Arsenic can pass through the placenta. Pregnant women chronically exposed to arsenic-contaminated drinking-water are at increased risk for spontaneous abortion, stillbirth and preterm birth. In utero and early-life exposures to arsenic have been linked to the development of lung cancer and bronchiectasia later in life. A very high exposure to inorganic arsenic can cause infertility. It is observed that inorganic arsenic can also damage DNA.

The organic arsenic compounds monomethylarsonic acid and dimethylarsinic acid are the active ingredients of some herbicides and are metabolites of inorganic arsenic. On the basis of sufficient evidence of cancer in experimental animals and because monomethylarsonic acid is extensively metabolized to dimethylarsinic acid, both compounds are classified as possibly carcinogenic to humans (Group 2B).

\section{Current arsenic remediation techniques}

The most commonly used arsenic removal methods are oxidation, reduction, precipitation, ion exchange, adsorption, lime treatment, solid-liquid separation, physical exclusion, biological removal processes and reverse osmosis. Other techniques are distillation, coagulation with metal salts, iron or manganese removal method. Some alternative technologies are Iron oxide coated sand method, sulphur modified iron method, Granular ferric hydroxide method, Iron filing and photo oxidation method. Substituting high-arsenic sources such as groundwater, with low-arsenic, microbiologically safe sources such as rain water and treated surface water.

Acid washing method (using aqueous acidic solution to extract water soluble arsenic), Solidification and stabilization method (by injecting polymers and other stabilizing compounds into ground), capping (placing hard cover over soil) and Soil removal (excavation) method (2 and 4$)$.

\section{Remedial researches in progress}

Researchers at the University of Georgia first used phytoremediation technology in 1996. They inserted bacterial genes -which coded for an enzyme that converts mercury into an inert form - into Arabidopsis [5] This experiment remains unique not only because it used bacterial genes to create a transgenic plant species, but also because it incorporates the phytoremediation techniques of phytoextraction, phytodegradation and phytovolatilization [6]. It has been reported that plants initially developed this ability to hyperaccumulate nonessential metallic compounds as a means of protecting themselves from herbivorous predators, which would experience serious toxic side effect from ingestion of the hyperaccumulator's foliage [7].

Some researches show that trees are ideal in the remediation of heavy metals because they can withstand higher concentrations of pollutants due to their large biomass, they can accumulate large amounts of the contaminants in their systems because of their size, they can reach an huge area and great depths due to their extensive root systems, they can stabilize an area and prevent erosion, and hence the spread of the contaminant, because of their perennial presence. They can also be easily harvested and removed from the area with minimal risk, effectively taking with them a large quantity of the pollutants that were once present in the soil [8]. The introduction of hyperaccumulating genes - as well as genetic information that would better prepare these species to deal with diverse climatic conditions, up-regulate this hyperaccumulation, or increase the organism's growth rate and overall size - into these model agricultural species would undoubtedly accelerate the remediation process and result in faster removal of environmental stress from the ecosystem.

Phytoremediation of heavy metals from the environment serves as an excellent example of the process of plant-facilitated bioremediation and its role in removing environmental stress. The cost of phytoremediation could be as much as 20 times less expensive, making this practice far less prohibitive than previous methods. A plant's ability to phytoextract certain metals is a result of its dependence upon the absorption of many metals - such as zinc, manganese, nickel, and copper - to maintain natural function. Most plants only accumulate these essential elements and prevent all others from entering. However, some plants, termed "hyperaccumulators", extract and store extremely high concentrations (in excess of 100 times greater than nonaccumulator species) of metallic elements. Research has shown that these hyperaccumulators often do not exclude non-essential metals in the absorption process, thus resulting in plants that can extract high levels (1-2\% of their biomass) of pollutants from contaminated soil [9].

Scientists, again from the University of Georgia, have developed a transgenic plant to combat this serious problem using the typical research model organism, Arabidopsis. By inserting bacterium genes 
into this plant, the researchers were able to make it much more tolerant to the presence of arsenic and thus increase its ability to extract arsenic from the soil. Because Arabidopsis is not an effective bioremediator, these researchers are now trying to extend this technology to cottonwood trees [5].

Some scientists reported that high levels of arsenic in the water supply are the result of practices used during the Green Revolution of the 1960's, such as large-scale irrigation and field flooding that have brought arsenic out of the soil and allowed it to enter the water supply. Arsenic build-up is also a result of by products that escape from chemical manufacturing sites [10]. Chinese Brake fern (Pteris vittata L.) has some potential to remove arsenic from groundwater, as reported in some researches [11].

Reported of Pteris multifida and Pteris oshimensis to hyperaccumulate arsenic in their fronds with high concentrations in addition to $P$. vittata and $P$. cretica var. nervosa, have been identified as arsenic hyperaccumulators [12]. Some scientists experimented the growth response of Vetiveria zizanioides amended with organic amendments to arsenic in contaminated soils and its ability to sequester arsenic. The test results indicate that the plants exhibited high tolerance to arsenic in the soils and their normal growth continued even though arsenic concentration reached $500 \mathrm{mg} / \mathrm{kg}$ [13].

It has been recorded that one species of fern (Dryopteris filixmas), three herbs (Blumea lacera, Mikania cordata, and Ageratum conyzoides), and two shrubs (Clerodendrum trichotomum and Ricinus communis) were found to be suitable for phytoremediation. Arsenic bioconcentration and translocation factors $>1$ suggest that these plants are arsenic tolerant accumulators with potential use in phytoextraction. Three floating plants (Eichhornia crassipes, Spirodela polyrhiza and Azolla pinnata) and a common wetland weed (Monochoria vaginalis) also showed high BCF and TF values; therefore, these plants may be promising candidates for cleaning up arsenic contaminated surface water and wetland areas [14].

In plant mechanisms, arsenate reductase reduces arsenate to arsenite with the help of thioredoxins or glutaredoxins, which serve as electron donors. Arsenite can be subsequently stored in the plant vacuole. In one study, an Arabidopsis thaliana transgenic plant was engineered to express bacterial arsenate reductase and glutamylcysteine synthase, which enhanced its ability to store two to three times more arsenic per gram of tissue than the non-transgenic plant [5].

Some researchers reported that Bassia scoparia (Chenopodiaceae), Inula viscosa (Asteraceae), Solanum nigrum (Solanaceae), and Hirschfeldia incana (Brassicaceae) had the highest values for arsenic accumulation [15]. P. vittata is effective in remediating arsenic contaminated groundwater to meet recommended standards [16]. Shrub of willow (Salix spp) has the ability of arsenic tolerance and uptake [2]. Wetland aquatic plant Colocasia esculenta L. is fastest arsenic remover [17]. Thelypteris palustris is may be a good candidate for remediation of arsenic soil contamination levels of $<$ or $=500$ microg/L arsenic as reported by a group [18].

Reports state that some aquatic plants have been reported to accumulate high level of arsenic from contaminated water [19]. Water hyacinth (Eichhornia crassipes), duckweeds (Lemna gibba, $L$. minor, Spirodela polyrhiza), water spinach (Ipomoea aquatica), water ferns (Azolla caroliniana, Azolla filiculoides, and Azolla pinnata), water cabbage (Pistia stratiotes), hydrilla (Hydrilla verticillata) and watercress (Lepidium sativum) have been studied to investigate their arsenic uptake ability and mechanisms, and to evaluate their potential in phytoremediation technology. It has been suggested that the aquatic macrophytes would be potential for arsenic phytoremediation.

Reports with the application of leachate, kenaf was also found to have higher biomass and subsequently recorded $11 \%$ higher bioaccumulation capacity, indicating its suitability for phytoextraction ofleachate contaminated sites [20]. Observation that the phytoextraction of arsenic contaminated soil by Pteris vittata was beneficial for growing rice resulted in rice grain yield $14 \%$ after two growing cycle and $8 \%$ after the one growing cycle of decreased arsenic content in rice grain of $<1 \mathrm{ppm}$ [21]. There was a mean improvement in rice grain yield $14 \%$ after two growing cycle and $8 \%$ after the one growing cycle of brake fern. Scientists found that Micranthemum umbrosum can be an effective accumulator of $\mathrm{Cd}$ and a hyper-accumulator of arsenic, as it can lower arsenic toxicity to a level close to the limit recommended by the World Health Organization $(0.01 \mu \mathrm{g}$ arsenic $\mathrm{mL}(-1)$ [22].

Some researchers observed that Abelmuscus esculentus is a hypoaccumulator and is sensitive to arsenic chloride [23]. When co-cultivated with Brassica juncea. Showing less of metal toxicity because Brassica juncea being hyperaccumulator of arsenic chloride, accumulate more metal and save Abelmuscus esculentus. It is suggested by them that Brassica juncea, Hk. F. \&T. is best suited for remediating arsenic contamination.

Some researchers observed that, the high capacity of roots to take up $\mathrm{Pb}$ and $\mathrm{As}(\mathrm{DF}>1)$ is indicative this plant is a good bioaccumulator for these metals [24]. Therefore, phytostabilisation is the mechanism at work in Melastoma malabathricum's uptake of $\mathrm{Pb}$, while phytoextraction is the dominant mechanism with arsenic [25]. The role of bores in the soil layer for pumping of water has also been reported to be a source for dissolution of arsenic in groundwater [26].

\section{Conclusion}

A number of arsenic treatment techniques have been recommended or they are being used so far, but still paucity exists where practically feasible and less expensive and eco-friendly technique for remediation of arsenic is urgently required. Shortlisting the plant species that can be used for the remediation of arsenic contamination is also needed. Researches for phytoextraction and hyperaccumulation, to combat arsenic menace, by selected botanical tools also needs to explored. In light of the above study, the subject needs to be brought in to light of the studies; and proper and strategic studies need to be conducted.

\section{Acknowledgement}

The authors are thankful to Prof. B.D. Tripathi, CAS in Botany, Banaras Hindu University, Varanasi, U.P. for his support in proofreading the manuscript. The authors are also thankful to Prof. P.P. Upadhyaya, Head, Department of Botany, DDU Gorakhpur University, Gorakhpur, U.P. The second author is also thankful to University Grants Commission, New Delhi for funding the present study.

\section{References}

1. Neila S, Khiari L, Soulwene K, Yahmed Amira B, Ben Rejeb Asma, et al (2011) Characteristics and Biological Treatment of Leachates from a Domestic Landfill, Hydrol Current Res. 2011, S3: 001.

2. Dwivedi AK (2013) Arsenic in Groundwater: An Issue Beyond Boundary, In: Rajkumar D, Lal J.K (eds.) Biodiversity Conservation \& Sustainable Development Centre for Biological Research, Puthalam, Tamil Nadu, India: 30-43.

3. US EPA (2000) Technologies and Costs for Removal of Arsenic from Drinking Water. Prepared by International Consultants, Inc. and Malcolm Pirnie, Inc. under Contract with the USEPA No. 68-C6-0039.

4. Dwivedi AK (2012) Groundwater and Arsenic: A Mini-review. In: Pandey RK (eds.) Environmental Degradation vis-à-vis Biodiversity, New Uttam Prakashan, Gorakhpur: 33-48. 
Citation: Dwivedi AK, Srivastava S, Dwivedi S, Tripathi V (2015) Natural Bio-Remediation of Arsenic Contamination: A Short Review. Hydrol Current Res 6: 186. doi:10.4172/2157-7587.1000186

5. Rugh CL, Wilde HD, Stack NM, Thompson DM, Summers AO, et al. (1996) Mercuric ion reduction and the resistance in transgenic Arabidopsis thaliana plants expressing a modified bacterial mer A gene. Proceedings of the National Academy of Sciences of the United States of America 9: 3182-3187.

6. Doloressa G, Borisjuk Nikolai V, Borisjuk Ludmyla G, Kneer Ralf, Alexander $P$, et al. (1996) Use of plant roots for phytoremediation and molecular farming. Proceedings of the National Academy of Sciences of the United States of America 96: 5973-5977.

7. Pollard Joseph A, Baker Alan J (1997) Deterrence of herbivory by Zinc hyperaccumulation in Thlaspi caerulescens, New Phytologist 135: 655-658.

8. Dwivedi AK, Rahul Singh, Shashi (2008) Groundwater Pollution: Causes and Impact, Indian Science Cruiser, 22: 29-33.

9. Lasat MM (2000) Phytoextraction of metals from contaminated soil: a review of plant/soil/metal interaction and assessment of pertinent agronomic issues. Journal of Hazardous Substance Research 1-25.

10. Om Parkash D, Yujing L, Rosen Barry P, Jin S, David S, et al. (2002) Engineering tolerance and hyperaccumulation of arsenic in plants by combining arsenate reductase and y-glutamylcysteine synthetase expression. Nature Biotechnology 20: 1140-1145.

11. Tu S, Ma LQ, Fayiga AO, Zillioux EJ (2004) Phytoremediation of arseniccontaminated groundwater by the arsenic hyperaccumulating fern Pteris vittata L. Int J Phytoremediation 6: 35-47.

12. Wang HB, Ye ZH, Shu WS (2006) Arsenic uptake and accumulation in fern species growing at arsenic-contaminated sites of southern China: field surveys. [Journal Article, Research Support, Non-U. S. Gov't] Int J Phytoremediation 8 : 1-11.

13. Singh S, Juwarkar AA, Kumar S, Meshram J, Fan M, et al. (2007) Effect of amendment on phytoextraction of arsenic by Vetiveria zizanioides from soil, International Journal of Enviornmental Science and Technology 4: 339-344.

14. Mahmud R, Inoue N, Kasajima SY, Shaheen R (2008) Assessment of potential indigenous plant species for the phytoremediation of arsenic-contaminated areas of Bangladesh. Int J Phytoremediation 10: 117-130.

15. Gisbert C, Almela C, Vélez D, López-Moya JR, de Haro A, et al. (2008) Identification of As accumulation plant species growing on highly contaminated soils. Int J Phytoremediation 10: 183-194.
16. Natarajan S, Stamps RH, Saha UK, Ma LQ (2008) Phytofiltration of arseniccontaminated groundwater using Pteris vittata L: effect of plant density and nitrogen and phosphorus levels. Int J Phytoremediation 10: 220-233.

17. Jomjun N, Siripen T, Maliwan S, Jintapat N, Prasak T, et al. (2011) Phytoremediation of arsenic in submerged soil by wetland plants. Int Phytoremediation 13: 35-46.

18. Anderson LL, Walsh M, Roy A, Bianchetti CM, Merchan G (2011) The potential of Thelypteris palustris and Asparagus sprengeri in phytoremediation of arsenic contamination. Int J Phytoremediation 13: 177-184.

19. Rahman MA, Hasegawa H (2011) Aquatic arsenic: phytoremediation using floating macrophytes. Chemosphere 83: 633-646.

20. Meera M, Agamuthu P (2012) Phytoextraction of As and Fe using Hibiscus cannabinus $\mathrm{L}$. from soil polluted with landfill leachate. Int J Phytoremediation 14: 186-199.

21. Mandal A, Purakayastha TJ, Patra AK, Sanyal SK (2012) Phytoremediation of arsenic contaminated soil by Pteris vittata LI. Influence of phosphatic fertilizers and repeated harvests. Int J Phytoremediation 14: 978-995.

22. Islam MS, Ueno Y, Sikder MT, Kurasaki M (2013) Phytofiltration of arsenic and cadmium from the water environment using Micranthemum umbrosum (J.F. Gmel) S.F Blake as a hyperaccumulator. Int J Phytoremediation 15: 10101021.

23. Selvaraj K, Sevugaperumal R, Ramasubramanian V (2013) Phytoremediation of Arsenic Chloride by Indian Mustard (Brassica Juncea), Indian Journal of Fundamental and Applied Life Sciences 3: 184-191.

24. Selamat SN, Abdullah SR, Idris M (2014) Phytoremediation of lead (Pb) and arsenic (As) by Melastoma malabathricum L. from contaminated soil in separate exposure. Int J Phytoremediation 16: 694-703.

25. Thomas SY Choong, TG Chuah, Y Robiah, FL Gregory Koay, I Azni, et al (2007) Arsenic toxicity, health hazards and removal techniques from water: an overview, Desalination 217: 139-166.

26. Dwivedi AK, Shashi J Singh (2006) Water pollution and groundwater recharging Current Science, 91: 407-408. 